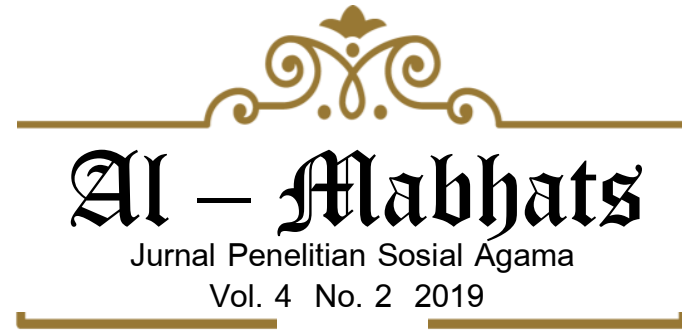

\title{
KEBIASAAN YANG MENJADI HUKUM ADAT LINTAS KELUARGA \\ (Studi Kasus Kunjungan Setiap Hari Raya Besar Antar Umat Beragama Di Sulawesi Utara)
}

\author{
Prasetio Rumondor \\ Universitas Islam Negeri Sunan Kalijaga Yogyakarta \\ e-mail: thiorumondor@gmail.com
}

Anisa Jihan Tumiwa

Institut Agama Islam Negeri Manado

e-mail: anisa.tumiwa@iain-manado.ac.id

ABSTRACT

The Purpose of writing this articles is to find out the interactions and habits of the people on major holidays between religious communities in North Sulawesi. This study uses qualitative research methods, with data collection techniques based on observations, interviews and documentation studies, as well as sociological approaches with studies cross-sectional. The results of this study show that interfaith visits, especially by each family, are still strongly bound by kinship but have distance and boundaries from each religion. Then, there are legal causes and legal consequences that occur from customary law visit when religious feast day are smaller in scope, namely the family which will automatically influence the interaction of the people of North Sulawesi.

Keywords: Visits; Feast Day; Common Law; Cross-Family; Understanding

\begin{abstract}
ABSTRAK
Penelitian ini bertujuan untuk mengetahui interaksi dan kebiasaan masyarakat pada hari raya besar antar umat beragama di Sulawesi Utara. Penelitian ini menggunakan metode penelitian kualitatif, dengan teknik pengumpulan data berdasarkan hasil observasi, wawancara dan studi dokumentasi, serta pendekatan sosiologi dengan studi cross-sectional. Adapun hasil penelitian ini bahwa kunjungan antar umat beragama terkhususnya oleh setiap keluarga masih terikat kental dengan tali persaudaraan namun mempunyai jarak dan batasan dari masing-masing agamanya. Kemudian, adanya sebab-sebab hukum dan akibat hukum yang terjadi dari hukum adat kunjung-mengunjungi ketika hari-hari besar keagamaan yang dalam lingkup lebih kecil yaitu keluarga yang secara otomatis akan mempengaruhi interaksi masyarakat Sulawesi Utara.
\end{abstract}

Kata Kunci: Kunjungan; Hari Raya; Hukum Adat; Lintas Keluarga; Pemahaman 


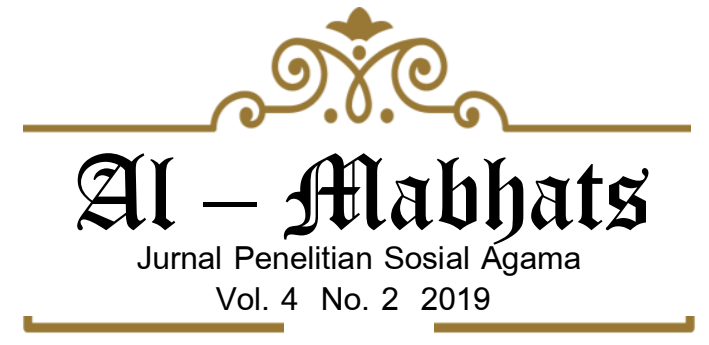

\section{A. PENDAHULUAN}

Manusia pada hakikatnya tidak mungkin terlepas dari "hidup intern pribadi" dan ekstern kehidupan antar pribadi". Hidup intern pribadi tersebut merupakan cerminan bahwa manusia itu sebagai makhluk individu dan sekaligus makhluk Tuhan, sedangkan kehidupan ekstern antar pribadi merupakan cerminan bahwa manusia itu sebagai makhluk sosial (Albani, Daulay, Susanti, \& Syam, 2017:9). Sesuai dengan kodrat alam manusia sejak lahir hingga ia meninggal dunia hidup bersma-sama dengan manusia lain dilingkungan yang sama atau dengan kata lain manusia tidak bisa hidup menyendiri atau terpisah dari kelompok manusia lainnya, karena manusia adalah makhluk sosial yang saling membutuhkan satu sama lain. Oleh karena manusia saling mempunyai kebutuhan satu sama lain yang tidak dapat diwujudkan seorang diri saja tanpa bantuan dari manusia lainnya, maka untuk itu mereka harus hidup bermasyarakat (Arrsjad, 2000:1-2). Dalam hidup bermasyarakat dihadapkan dengan ruang lingkup yang lebih kecil yaitu kehidupan atau interaksi dalam keluarga yang seyogianya menjadi titik tumpu alur aktualisasi dalam bermasyarakat.

Sulawesi Utara khususnya kota Manado yang mendapat julukan serta penghargaan kota paling toleran di Indonesia, karena berbagai aktivitas antar umat beragama yang kerap kali menjadi sorotan publik dan media contohnya saling menjaga rumah peribadatan ketika tiba perayaan hari besar keagamaan serta turut meramaikan dan bahkan berpartisipasi untuk mensukseskan hal-hal yang berkaitan dengan keagmaan, contohnya umat kristiani di Manado pada bulan puasa sering membagikan ta'jil (makanan/snack untuk berbuka puasa) di sepanjang jalan pasar 45 dan simpangan taman kesatuan bangsa (TKB), dan beberapa daerah lainnya di Sulawesi Utara yang melakukan hal serupa. Hal tersebut merupakan contoh kecil dari interaksi sosial sebagaimana yang dimaksud.

Kunjungan pada setiap perayaan hari besar yang dilakukan antar umat beragama yang biasa disebut orang Manado dengan kata pasiar atau pesiar sudah menjadi adat bahkan hukum adat bagi 


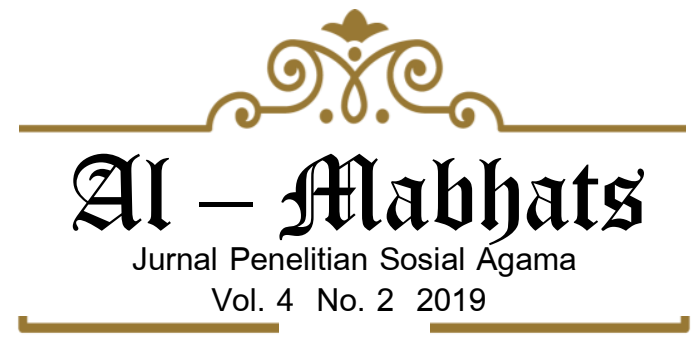

beberapa keluarga tertentu yang apabila tidak dilaksanakan maka akan menimbulkan sebab-sebab adanya sanksi yang harus diberlakukan dalam keluarga tersebut dengan tujuan agar hubungan antar keluarga semakin erat. Namun seiring berjalannya waktu pada kenyataannya sanksi yang diberikan tidak menjadikan hubungan antar keluarga semakin erat malah justru sebaliknya. Oleh karena itu hal tersebut yang akan ditelaah dari sudut pandang terkecil yaitu keluarga dan akan berimplikasi kepada masyarakat umumnya serta aktualisasi khususnya.

Penelitian ini menggunakan metode penelitian kualitatif. Dalam pengumpulan datanya berdasarkan hasil observasi, wawancara dan studi dokumentasi, serta pendekatan yang kami gunakan ialah pendekatan sosiologi. Di dalamnya terdapat beberapa jenis pendekatan penelitian yang digabungkan untuk mengumpulkan data yang ada namun tetap pada struktur metedologi tersebut, yaitu studi cross-sectional yang merupakan suatu pengamatan pada suatu daerah yang luas dalam jangka waktu tertentu (Soyomukti, 2016:65). Kemudian, penulis juga menyajikan data empiris yang mengutamakan keadaan-keadaan dari pengalaman nyata yang ada di masyarakat (Soyomukti, 2016:67). Penelitian ini bertujuan untuk mengetahui interaksi dan kebiasaan masyarakat pada hari raya besar antar umat beragama di Sulawesi Utara.

\section{B. PEMBAHASAN}

\section{Mengenal Sulawesi Utara}

Sulawesi Utara adalah salah satu provinsi yang terletak di ujung utara Pulau Sulawesi dengan Ibukota terletak di kota Manado. Sulawesi Utara atau Sulut berbatasan dengan Laut Maluku dan Samudera Pasifik di sebelah timur, Laut Maluku dan Teluk Tomini di sebelah selatan, Laut Sulawesi dan provinsi Gorontalo di sebelah barat, dan provinsi Davao del Sur (Filipina) di sebelah utara (Wikipedia, 2017).

Sony Samual mengatakan bahwa Sulawesi Utara memiliki luas wilayah 13,581.64 km², dengan koordinat 1015'LU 124031'BT. Selain itu 


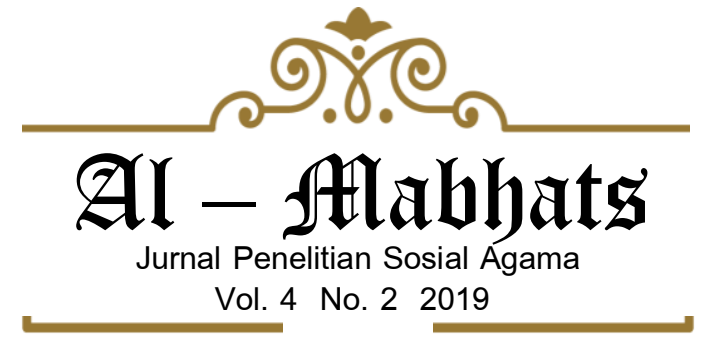

juga Sulawesi Utara memiiki paling tidak 2.412.118 Juta penduduk. Sulawesi Utara memiliki setidaknya 14 Kabupaten dan 3 Kota Madya dan 1 Ibukota Provinsi yaitu Manado. Selain itu, Sulawesi Utara memiliki 4 suku bangsa, yaitu suku Sangihe, suku Bolaang Mongondow, suku Minahasa dan suku Nusa Utara yang melepaskan diri dari suku Sangihe (Samual, 2017).

\section{Sejarah Sulawesi Utara}

Pada permulaan kemerdekaan Republik Indonesia, Daerah ini berstatus Keresidenan yang merupakan bagian dari Provinsi Sulawesi. Seiring dengan perkembangan pemerintahan, maka berdasarkan Peraturan Pemerintah no. 5 tahun 1960 Provinsi Sulawesi dibagi menjadi dua bagian yaitu Provinsi Sulawesi Selatan-Tenggara dan Provinsi Sulawesi Utara-Tengah. Untuk mengatur penyelenggaraan pemerintahan di Provinsi Sulawesi Utara-Tengah, maka berdasarkan Keputusan Presiden Republik Indonesia Nomor 122/m tahun 1960 tanggal 23 Maret 1960 ditunjuklah Mr. A.A. Baramuli sebagai Gubernur Kepala Daerah Tingkat I Sulawesi Utara-Tengah.

Sembilan bulan kemudian Provinsi Sulawesi Utara-Tengah dan Provinsi Sulawesi Selatan-Tenggara ditata kembali statusnya menjadi Daerah Tingkat I Sulawesi Utara-Tengah dan Daerah Tingkat I Sulawesi Selatan-Tenggara melalui Peraturan Pemerintah Pengganti Undang-Undang Nomor 47 /Prp/Tahun 1960. Wilayah Provinsi Daerah Tingkat I Sulutteng meliputi : Kotapraja Manado, Kotapraja Gorontalo, dan delapan Daerah Tingkat II masing-masing : Sangihe Talaud, Bolaang Mongondow, Minahasa, Gorontalo, Buol Toli-Toli, Donggala, Poso, dan Luwuk/Banggai. Dengan berlakunya Peraturan Pemerintah Pengganti Undang-Undang Nomor 47 Prp Tahun 1960 ini, maka dimulailah penyelenggaraan pemerintahan daerah-daerah otonomi Tingkat I Sulawesi, dimana Wilayah Sulawesi Utara merupakan bagian dari Daerah Tingkat I Sulawesi Utara-Tengah.

Pada tanggal 26 April 1966, Brigjen Soenandar Prijosoedarmo diganti oleh Residen Abdulah Amu sebagai Pejabat Gubernur Provinsi Sulawesi Utara berdasarkan Undang-Undang Nomor 18 Tahun 1965 


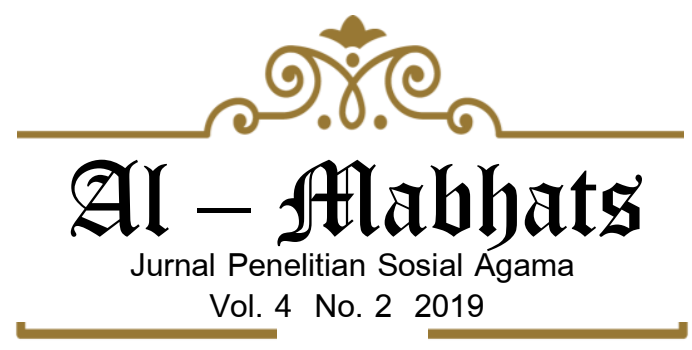

dimana salah satu ketentuan dalam undang-undang tersebut mengatur tentang tidak dirangkapnya lagi jabatan Ketua DPRD oleh Kepala Daerah. Dengan demikian terjadilah kekosongan jabatan kepemimpinan DPRD. Untuk mengisi kekosongan jabatan tersebut, Dewan Perwakilan Rakyat Daerah Tingkat I Sulawesi Utara melalui Keputusan nomor 19/dprd/1966 tanggal 12 mei 1966 menyerahkan caretaker pimpinan DPRD Tingkat I Sulawesi Utara kepada J. Minggu, T.B. Makaminang, Gandhi Kalulu dan G. Lalamentik (Sulutprov, 2017).

Sementara itu untuk membantu Pejabat Gubernur Abdullah Amu dalam menjalankan tugasnya, maka berdasarkan Surat Keputusan Pejabat Gubernur Kepala Daerah Tingkat I Sulawesi Utara. Nomor 274/1966 tanggal 30 Agustus 1966, telah dibentuk Badan Pekerja DPRD Tingkat I Sulawesi Utara yang disebut Steering Committee yang diketuai oleh F.W. Kumontoy, dan Badan Pemerintahan Harian (BPH) dengan para anggota Letkol Rumpokowiryo, Hasan Usman, Hamid Asagaf dan Abubakar Usman, dan Sekretaris Daerah Residen A.M. Jacobus.

Pada tanggal 10 Desember 1966 dengan berdasarkan Surat Keputusan Menteri Dalam Negeri Nomor 31/DGR/66 telah ditetapkan Pimpinan DPRD-GR Provinsi Sulawesi Utara dengan Ketua Ahmad Husain dan Wakil Ketua U.P. Dondo B.Sc., F.W. Kumontoy, dan Mayor (AL) J. Mamusung. Tugas yang dilaksanakan mereka adalah memilih Gubernur Sulawesi Utara yang definitif.

Pada tanggal 2 Maret 1967 di depan Sidang Paripurna Dewan Perwakilan Rakyat Daerah Tingkat I Sulawesi Utara, Brigadir Jenderal H.V. Worang diambil sumpahnya dan dilantik menjadi Gubernur Kepala Daerah Tingkat I Sulawesi Utara oleh Menteri Dalam Negeri Mayjen Gatot Suwagyo atas nama Presiden Republik Indonesia. H. V. Worang memegang jabatan sebagai Gubernur Kepala Daerah Tingkat I Sulawesi Utara selama 11 tahun 3 bulan, yaitu dari tanggal pelantikannya 2 Maret 1967 sampai dengan 20 Juni 1978.

Pada tanggal 4 Maret 1985, kembali sejarah Provinsi Daerah Tingkat I Sulawesi Utara mencatat penggantian Gubernur Kepala 


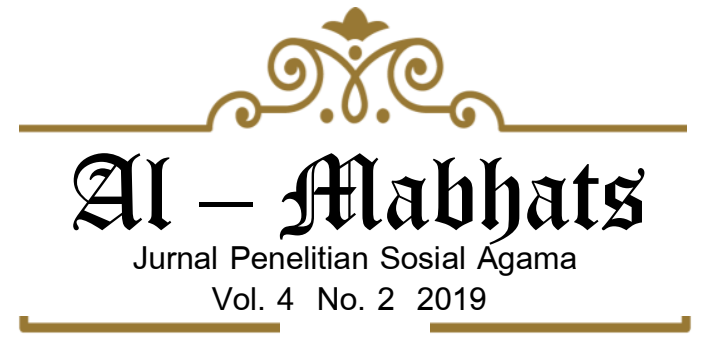

Daerah Tingkat I Sulawesi Utara untuk yang kesembilan kalinya. Brigadir Jenderal C.J. Rantung dilantik dalam Sidang Paripurna Khusus DPRD Provinsi Daerah Tingkat I Sulawesi Utara untuk menggantikan Pejabat lama Letjen (Purn) G.H. Mantik yang telah habis masa jabatannya. Pelantikan C.J. Rantung sebagai Gubernur yang kesembilan berdasarkan Surat Keputusan Presiden RI Nomor 45/M Tahun 1985 tanggal 18 Februari 1985, untuk masa jabatan 19851990.

Setelah mengakhiri periode tersebut, maka Pemerintah Pusat dan masyarakat Sulawesi Utara kembali memberikan kepercayaan dan meletakkan harapan di pundak Mayor Jenderal (Purn) C.J. Rantung untuk memimpin kembali Daerah Sulawesi Utara, berdasarkan Surat Keputusan Presiden Republik Indonesia Nomor 34/M Tahun 1990 tanggal 10 Februari 1990, yang pelantikannya dilakukan oleh Menteri Dalam Negeri Rudini atas nama Presiden Republik Indonesia untuk masa bakti kedua Tahun 1990 - 1995. Selama periode kepemimpinan Gubernur C.J. Rantung dari Tahun 1985-1995, dia dibantu oleh Wakil Gubernur Drs. A. Mokoginta, kemudian dilanjutkan oleh Drs. A. Nadjamudin.

Sementara itu, Sekretaris Wilayah Daerah Tingkat I Sulawesi Utara semasa kepemimpinan 10 tahun Gubernur C. J. Rantung, tercatat masing-masing Kolonel (Purn) I. Tangkudung, Kol. A.T. Dotulong, dan M. Arsjad Daud, S.H. Sedangkan Pimpinan DPRD Provinsi Daerah Tingkat I Sulawesi Utara, Ketua F. Sumampouw dengan Wakil-wakil Ketua M. Toha dan H. Hasan Usman, yang dilanjutkan oleh Pimpinan DPRD Hasil Pemilu 1997 yaitu Ketua F. Sumampouw dan Wakil-wakil Ketua Achmad H.S. Pakaya, F.P.D. Lengkey dan R. Tanos. Tahun 1995 kepemimpinan daerah dipercayakan kepada Mayjen TNI E.E. Mangindaan, dimana pada tanggal 1 Maret 1995 terpilih dan ditetapkan.

Pada tanggal 21 Juli 2005 untuk pertama kali di Indonesia dilakukan pemilihan Gubernur dan Wakil Gubernur Sulawesi Utara secara langsung oleh rakyat, dimana berhasil terpilih pasangan S.H. Sarundajang sebagai Gubernur Sulawesi Utara dan F.H. Sualang 


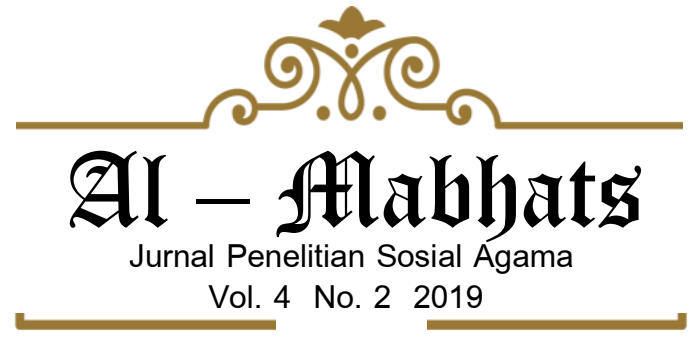

sebagai Wakil Gubernur Sulawesi Utara untuk masa bhakti 2005 2010. Sedangkan Ketua DPRD dijabat oleh Drs. Syarial Damapolii yang dibantu oleh wakil ketua masing-masing Djendri Keintjem, R. Pandegirot, dan Arthur Kotambunan. Untuk Sekretaris daerah selama periode pertama dipegang oleh Dr. Johanis Kaloh kemudian dilanjutkan oleh Drs. R.J. Mamuaja pada tahun 2006, sampai saat ini. Namun dalam masa tugas Drs. R.J. Mamuaja juga ditunjuk Plt. Sekretaris daerah yaitu berturut turut Hr. Makagansa dan Siswa Rahmat Mokodongan.

Dalam masa kepemimpinan S.H. Sarundajang dan F.H. Sualang, wilayah administrasi pemerintahan Sulawesi Utara mengalami ketambahan 4 (empat) kabupaten/kota baru pada tahun 2007 yakni Kota Kotamobagu berdasarkan Undang-undang Nomor 4 Tahun 2007, Kab. Minahasa Tenggara berdasarkan Undang-undang Nomor 9 Tahun 2007, Kab. Bolmong Utara berdasarkan Undangundang Nomor 10 Tahun 2007 dan Kab. Siau Tagulandang Biaro berdasarkan Undang-undang Nomor 15 Tahun 2007. Pada tahun 2008 ketambahan lagi 2 (dua) kabupaten baru yakni Kabupaten Bolaang Mongondow Timur berdasarkan Undang-undang Nomor 29 Tahun 2008 dan Kabupaten Bolaang Mongondow Selatan berdasarkan Undang-undang Nomor 30 Tahun 2008 sehingga jumlah daerah otonom di Provinsi Sulawesi Utara menjadi 11 (sebelas) kabupaten dan 4 (empat) kota.

3. Sulawesi Utara dengan Filosofinya "Torang Samua Basudara", Motto "Sitou Timou Tumou Tou" dan Tradisi "Pogugutat"

\section{a. Sulawesi Utara dengan Filosofinya "Torang Samua Basudara"}

Filosofi Torang Samua Basudara adalah kearifan lokal masyarakat Sulawesi Utara. Ciri yang paling menonjol di dalamnya adalah keterbukaan. Hal ini dapat dilihat dari sikap saling menghargai, tolong-menolong atau saling bantu-membantu. Kita semua bersaudara, antara yang satu dengan yang lainnya, hiduplah 


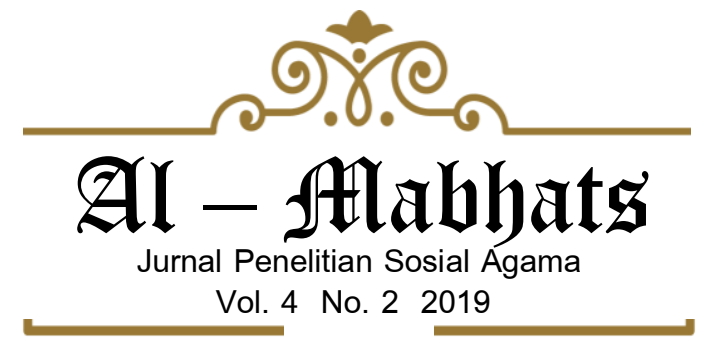

dalam keadaan baik dan saling menyayangi merupakan pesan moral yang sangat mulia untuk hidup rukun dan damai (Mantu, 2015:). Masyarakat Sulawesi Utara memiliki keterbukaan yang tercermin dalam hidupnya yang dapat dilihat dari sikapnya, misalnya sikap bekerjasama. Hal yang paling menonjol adalah dibidang pertanian, bila ada anggota masyarakat mempunyai sawah atau kebun maka masyarakat akan saling membantu dan tolong menolong secara bergantian dalam membuka lahan baru atau membajak sawah.

Di Minahasa, bentuk kerja sama ini disebut Mapalus; di Sangihe disebut Mapaluse; di Bolaang Mongondow disebut Mopasad. Walaupun mapalus, mapaluse dan mopasad, merupakan tiga nama dengan sebutan berbeda, namun memiliki tujuan yang sama, yaitu saling bekerja sama dalam menyelesaikan suatu pekerjaan (Mantu, 2015, p. 57). Mapalus, mapaluse dan mopasad sebenarnya hanya pada masyarakat tani, tetapi mulai berkembang misalnya arisan, ajang silahturahmi dalam bentuk: rukun keluarga, marga, dan dalam satu sub etnis, arisan seperti membawa bahan pokok makanan atau makanan jadi bila ada yang berduka ke rumah duka secara bergiliran. Selain itu, kerjasama lainnya seperti menjaga rumah ibadah secara bergantian antar pemeluk agama lain. Dari bentuk kerja sama inilah mulai tercipta rasa saling menghargai, menyayangi dan saling mencitai dalam wujud hidup rukun intern kelompok. Selanjutnya dari hidup rukun intern kelompok berkembang sebagai cikal bakal hidup rukun antarkelompok, baik dengan kelompok masyarakat penduduk asli, atau yang sudah berasimilasi maupun dengan kelompok masyarakat pendatang baru (Mantu, 2015, p. 65). Adapun aspek-aspek yang terkandung dalam filosofi Torang Samua Basudara, pertama adanya sikap toleransi yang tinggi. Kedua, saling membantu dan memberi tanpa melihat latar belakang atau darimana orang tersebut berasal. Ketiga, sebagai pandangan hidup. Keempat, rasa hormat yang tinggi. Dan nilai demokrasi.

\section{b. Minahasa dengan Motto "Sitou Timou Tumou Tou"}

Motto "Sitou Timou Tumou Tou" artinya manusia hidup hanya untuk memanusiakan orang lain. Dr. Sam Ratulangi menyimpulkan 


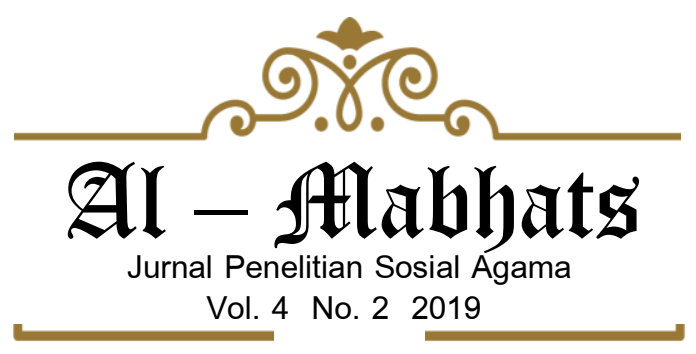

bahwa realitas kehidupan bangsa Minahasa yang toleran, saling membantu, akrab dengan sesama serta saling menghargai segala bentuk perbedaan yang melewati sekat-sekat perbedaan kronis, dalam hal ini perbedaan agama adalah hambatan. Dahulu, Sitou Timou Tumou Tou sangat nampak muncul pada proses adaptasi antara pengungsi "Perang Jawa" (1825-1830) (Djakara, 2003:13-14). Beragama Islam dan masyarakat Tondano, Minahasa Beragama Kristen. Orang Jawa yang ketika itu dipimpin oleh Kyai Modjo, hingga kini telah hidup dengan harmonis dengan masyarakat setempat, bahkan beberapa putranya pernah menjadi Walikota Manado (Hi. Andi Buchari) dan wakil propisi di MPR-RI (Ishak Pulukadang). Rasa saling terbuka dan menerima perbedaan membuat masyarakat Jawa yang tinggal dalam pembuangan tersebut, sekalipun beragama Islam labeli diri mereka dengan sebutan Niyaku Toudano (aku orang Tondano) (Tumenggung Sis, 2003:35).

\section{c. Bolaang Mongondow dengan Tradisi "Pogugutat"}

Manusia merupakan makhluk sosial yang pasti membutuhkan manusia yang lain, manusia tak akan mampu hidup sendirian dan pasti membutuhkan bantuan orang lain. Makanya dalam hidup seseorang harus membangun kerjasama yang baik. Oleh karena itu, kerjasama memiliki nilai-nilai sosial seperti mengahargai pendapat orang lain, tanggungjawab, kebersamaan dan sikap peduli. Begitu juga dengan tradisi pogogutat di Bolaang Mongondow yang hakekatnya untuk sarana interaksi dan saling beradaptasi antara warga yang satu dengan yang lainnya. Tujuannya untuk menjalin komunikasi, mempererat tali silaturahmi, dan dapat membangun kerjasama antara warga yang lain.

Tradisi pogogutat artinya gotong royong, aplikasi tradisi ini adalah sekumpulan masyarakat luas maupun di lingkungan sekitarnya. Adapun kerjasama berupa keinginan untuk memberikan bantuan baik berupa jasa maupun dalam rangka mensukseskan hajatan keluarga. Sebelum pelaksanaan kegiatan masyarakat berbodong-bondong mengatarkan bantuannya ke rumah keluarga yang berhajat (Mamonto \& Muhammad, 2019:38). 


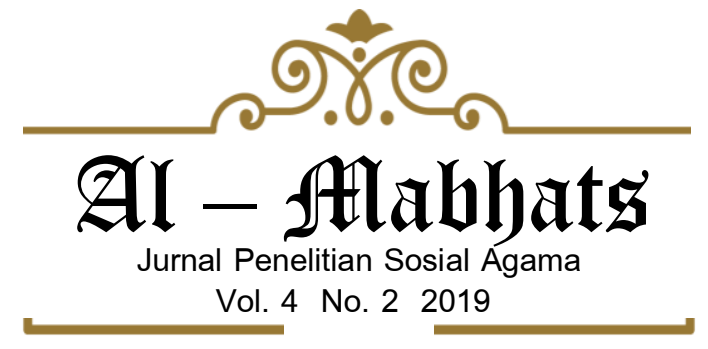

\section{Interaksi Sosial Setiap Hari Raya Besar Antar Umat Beragama Di Sulawesi Utara}

Dalam pembahasan ini penulis akan menjelaskan tentang interaksi sosial yang lebih dikhususkan ke lingkup keluarga yang ada di Sulawesi Utara tentunya dengan dilatar belakangi oleh suku-suku yang ada di bumi nyiur melambai ini dan menjelaskan serta mengaitkan juga membandingkan tingkat keberagaman yang ada di manado dengan beberapa kota besar lainnya yang semerbak baunya dengan keberagaman dan interaksi antar umat beragama. Interaksi yang dimaksud adalah kunjungan pada setiap perayaan hari besar keagamaan serta suku yang dimaksud ialah salah satu suku yang ada yaitu suku minahasa dan dengan diperkecil pada lintas keluarga saja.

Dewasa ini sesuai dengan fakta yang terjadi pada masyarakat dan keluarga yang ada di Manado khususnya sering terjadi aktivitas saling kunjung mengunjungi ketika hari-hari besar keagamaan, contohnya ketika Idul Fitri, Idul Adha, Natal, Waisak, dan Imlek. Menurut Irwan Musa SE, M.Si selaku Ketua Forum antar Umar Beragama, beliau menuturkan bahwa sikap toleransi tersebut sangat kental terasa karena rata-rata umat beragama di Manado masih mempunyai garis keturunan dan ikatan kekeluargaan secara bioligis, jadi walaupun berbeda agama namun masih dalam satu lingkup keluarga dengan kata lain masih ada ikatan darah (Musa, 2017)

Dalam survei pengumpulan pendapat umum yang dilakukan Centre for the Study of Development and Democracy (CESDA), yaitu sebuah pusat studi yang didirikan dan berada dalam LP3ES, yang dilakukan di tiga kota besar, Jakarta, Surabaya dan Medan, dari tanggal 6 sampai dengan 20 Desember 1998, ditemukan hal-hal berikut: Tingkat kerukunan umat beragama di tiga kota besar tadi dalam kehidupan sehari-hari cukup tinggi. Sebagian besar responder menyatakan bahwa agama tidak menjadi pertimbangan dalam bertetangga (64,3\%), dan tidak terganggu kalau tetangganya beragama lain (88,8\%). Sementara itu, 97\% menyatakan akan membantu atau prihatin jika tetangganya yang beragama lain ditimpa musibah, 70,6\% 


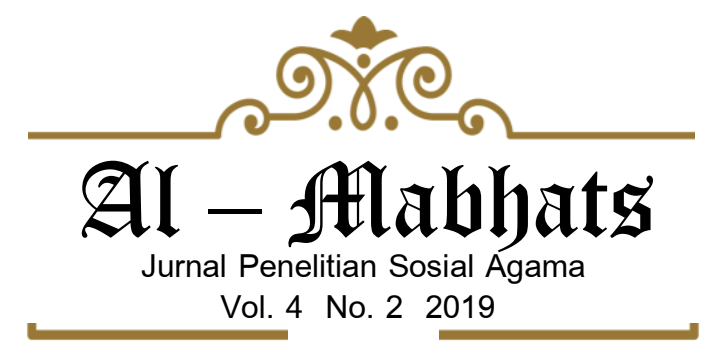

berpendapat bahwa agama tidak menjadi pertimbangan dalam memilih teman, dan $86,4 \%$ tidak terganggu dalam berhubungan dengan rekan sekerja yang tidak seagama. Lebih jauh mereka berpendapat bahwa dalam memilih karyawan seyogianya keahlian lebih dipertimbangkan daripada agama, atau agama tidak dijadikan pertimbangan (66,7\%) (Yewangoe, 2011:31). Saling mengucapkan selamat pada hari raya kepada penganut agama lain seperti Idul Fitri, Natal, Waisak dan Galungan, baik secara langsung maupun dengan kartu ucapan, disetujui 63,2\% masyarakat di tiga kota besar itu. Bahkan 95,5\% merasa senang atau biasa saja menerima ucapan selamat dari mereka yang beragama lain. Sikap yang lebih toleran juga diungkapkan dengan sikap menyetujui kehadiran dalam perayaanperayaan ibadah umat beragama lain (38,8\%) (Salim, 2017: 19). Dari tiga kota besar tersebut cukup banyak masyarakat yang bersedia untuk memberikan bantuan berupa sumbangan untuk pembangunan rumah ibadah dan bersedia menerimanya.

Data diatas membuktikan bahwa keberagaman dan kerukunan juga terjaga di beberapa daerah tersebut karena beberapa faktor sesuai dengan porsi jawaban masing-masing responden, kembali penulis meninjau fakta sosial dari akar pembahasan dalam hal ini kunjungan yang dilakukan antar umat beragama yang terjadi dilintas keluarga khususnya suku minahasa yang mendominasi Kota Manado menjadi daya tarik tersendiri untuk ditelaah. Sesuai dengan hasil pengamatan yang dilakukan penulis dan bahkan yang dirasakan sendiri ialah adanya sebab-sebab hukum dan akibat hukum yang timbul dari hukum adat kunjung-mengunjungi ketika hari-hari besar keagamaan.

Saling berkunjung ketika ada perayaan hari-hari besar merupakan kewajiban yang harus mutlak dilaksanakan oleh suku Minahasa. Jadi, apabila tidak dilaksanakan maka akan ada sanksi, sanksi yang diberikan ialah tidak akan mengunjungi keluarga yang sedang dalam perayaan hari besarnya, misalnya pada saat hari raya natal kemudian keluarga yang beragama islam tidak berkunjung maka pada saat hari raya idul fitri keluarga yang beragama kristen tidak akan datang berkunjung pula, tanpa disadari tahun demi tahun 


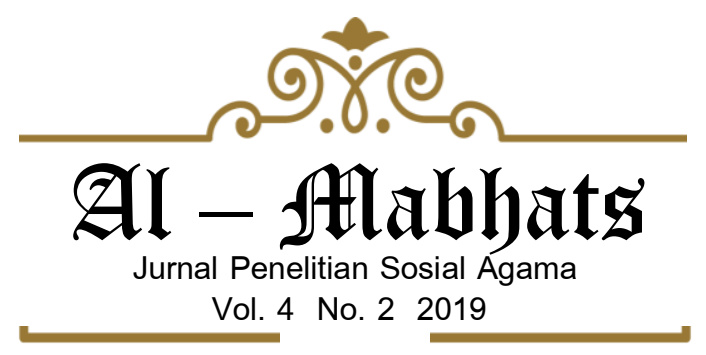

terlewati dan hal tersebut masih terus berlanjut yang pada akhirnya membuat hubungan keluarga menjadi renggang dan seolah telah dibangun secara otomatis sebuah tembok pemisah diantara keluarga tersebut.

Adapun beberapa alasan yang bisa menjadi faktor terjadinya masalah sebagaimana yang telah dipaparkan diatas. Eske Tumiwa mengatakan bahwa kesibukan dari masing-masing keluarga pada saat hari-hari raya besar yang tidak memungkingkan untuk saling berkunjung, kemudian sifat gengsi dan tidak mau mengalah antara satu dengan yang lainnya dikarenakan stagnannya interaksi dan tidak ada reaksi pada saat tidak terjadinya sebuah proses kunjungmengunjungi dalam kurun waktu yang panjang, walaupun dapat diakui bahwa tidak semua orang berandil dalam kegiatan yang lebih condong ke arah negatif tersebut (Tumiwa, 2018).

Istilah hukum adat merupakan terjemahan dari istilah (bahasa) Belanda "Adat Recht" yang awalnya dikemukakan oleh Prof. Dr. Christian Snouck Hurgronje nama muslimnya H. Abdul Ghafar di dalam bukunya berjudul "De Atjehers" menyatakan bahwa: Hukum adat adalah adat yang mempunyai sanksi, sedangkan adat yang tidak mempunyai sanksi adalah merupakan kebiasaan normatif, yaitu kebiasaan yang terwujud sebagai tingkah laku dan berlaku di dalam masyarakat. Pada kenyataan antara hukum adat dengan adat kebiasaan itu batasnya tidak jelas (Setiady, 2009:8).

Hukum adat merupakan hukum tradisional masyarakat yang merupakan perwujudan dari suatu kebutuhan hidup yang nyata serta merupakan salah satu cara pandangan hidup yang secara keseluruhannya merupakan kebudayaan masyarakat tempat hukum adat tersebut berlaku. Hukum adat juga merupakan nilai-nilai yang hidup dan berkembang di dalam masyarakat suatu daerah. Walaupun sebagian besar hukum adat tidak tertulis, namun ia mempunyai daya ikat yang kuat dalam masyarakat (Sumanto, 2018:82-183).

Selain itu, perihal Hukum Adat (Adatrecht) adalah sistem hukum yang tumbuh dan berkembang dari kebiasaan-kebiasaan (customs) dalam masyarakat. R. Soepomo (1983), merumuskan, 


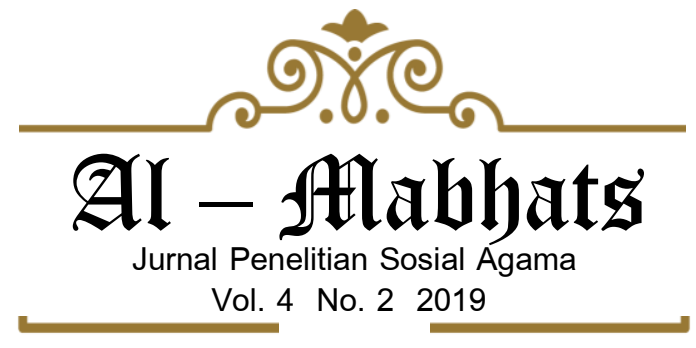

Hukum Adat adalah hukum non-statutior yang sebagian besar adalah hukum kebiasaan dan sebagian kecil Hukum Islam (Konoras, 2017:7). Ada sanksi tersendiri dari masyarakat jika melanggar aturan hukum adat. Hukum adat yang hidup dalam masyarakat ini bagi masyarakat yang masih kental budaya aslinya akan sangat terasa (Sumanto, 2018:183). Kemudian jika ditarik dari segi hukum Islam maka kaidah yang dipakai ialah, kaidah ushul fiqh yakni "Al-'adatu Muhakkamah" yang berarti Adat adalah Hukum, dari hal tersebut dapat diambil benang merah bahwasanya sebuah kebiasaan dapat menjadi sebuah hukum.

Hukum sebagai suatu kaidah di dalamnya merupakan seperangkat norma-norma yang memuat anjuran, larangan dan sanksi yang salah satu fungsi p.okoknya sebagai sarana kontrol sosial, dengan tujuan menjaga ketertiban, keseimbangan sosial dan kepentingan masyarakat. Sebagai seperangkat norma yang berfungsi dan bertujuan demikian itu, maka hukum pertama-tama akan hadir sebagai sesuatu yang bersifat law in the books, memuat ancangan hipotesis tentang batas-batas Perilaku manusia yang boleh dan tidak boleh dilakukan serta memberi ancaman sanksi apabila ada di antara anggota masyarakat yang melakukan pelanggaran (Bukido, 2016:11).

Aqila F Sumohardjo mengatakan bahwa salah satu sisi positif dari berlakunya hukum adat sebagaimana dimaksud adalah menjaga kebiasaan yang sudah dilakukan sejak dahulu, namun tidak sedikit pula sisi negatif dari kebiasaan tersebut salah satunya adalah renggangnya hubungan antar keluarga (Sumohardjo, 2018).

Oleh karena itu penulis mengambil jalan tengah beserta tujuan dari analisis penulis yaitu, mengingat dan menimbang dari salah satu tujuan hadirnya hukum ialah adanya Kemanfaatan Hukum dan juga seperti apa yang telah dijabarkan dalam sebuah Jurnal Hasanuddin Law Reveiw yaitu, "law is a matter of man and not merely a matter of regulation, and law exists for humans, not vice versa. Law should flow." The same thing was stated by Eugen Ehrlich in Bernard L. Tanya," 8 who says that law is not an intellectual concept but is the reality of the relationship between man himself, the law is the relationship between humans. Humans" 


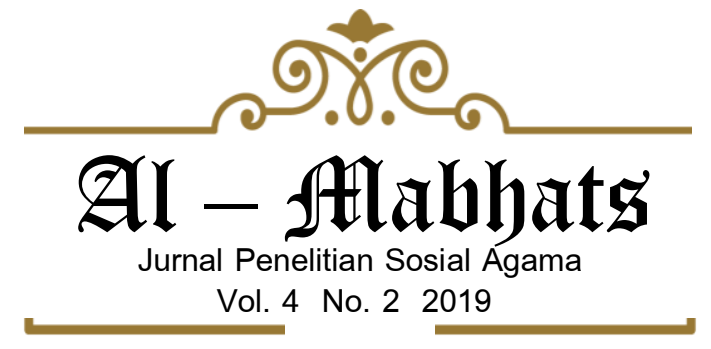

yang berarti "hukum adalah masalah manusia dan bukan hanya masalah regulasi, dan hukum ada untuk manusia, bukan sebaliknya. Hukum harus mengalir." (Bukido, Rumkel, Wekke, \& Palm, 2018:245). Hal yang sama dinyatakan oleh Eugen Ehrlich, yang mengatakan bahwa hukum bukanlah konsep intelektual tetapi adalah realitas hubungan antara manusia itu sendiri, hukum adalah hubungan antara manusia (Tanya, Simanjuntak, \& Hage, 2007:164-165). Maka sanksi hukum untuk tidak saling mengunjungi jika salah satu keluarga tidak bisa atau berkesempatan hadir pada saat perayaan hari raya besar sebaiknya ditiadakan dan syogianya masing-masing keluarga membuang sifat ego dan gengsi untuk tetap tidak saling mengunjungi, melihat perkembangan zaman yang berubah jadi hukum adat tersebut dituntut untuk dinamis pula.

\section{SIMPULAN}

Pada hakikatnya semua silaturahim antar umat beragama perlu dieratkan dan dilestarikan secara turun menurun, perihal terkait perbedaan agama dalam satu keluarga kemudian menimbulkan sebab dan akibat dari hukum adat yang diterapkan, alangkah lebih baiknya agar dapat disesuaikan dengan kondisi dan perubahan zaman agar efek negatif yang diakibatkan dari hukum adat tersebut tidak meraja lela. Jadi hanya efek positif saja yang akan terasa bila di berlakukannya Hukum adat tersebut.

Dewasa ini yang harus dilakukan ialah, menghilangkan kebiasaan tidak saling mengunjungi apa bila salah satu keluarga tidak berkesempatan atau tidak mengunjungi keluarga yang lainnya pada saat perayaan hari besar dari masing-masing agama keluarganya. Kemudian mempererat hubungan antar keluarga melalui beberapa aktifitas pada saat semua keluarga terkumpul, karena dari aktivitas tersebut akan membuat kenangan dan dari kenangan akan lahirlah sebuah kerinduan, dari sebuah rindu yang tidak semu akan memberikan stimulasi untuk saling bertemu dan pada akhirnya bermuara pada aktualisasi kebiasaan yang akan menjadi hukum adat nan lebih baik lagi. 


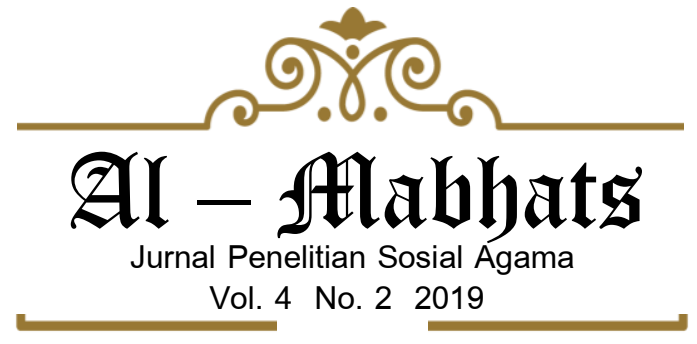

\section{DAFTAR PUSTAKA}

Albani, M. S., Daulay, M. N. H., Susanti, N., \& Syam, S. (2017). Ilmu Sosial Budaya Dasar. Jakarta: PT Raja Grafindo.

Arrsjad, C. (2000). Dasar-Dasar Ilmu Hukum. Jakarta: Sinar Grafika.

Bukido, R. (2016). Paradigm and Reality of Law Enforcement in Indonesia. Jurnal Ilmiah Al-Syir'ah, 4(1), 1-11.

Bukido, R., Rumkel, N., Wekke, I. S., \& Palm, E. (2018). Customary Law of Larwul Ngabal in the Implementation of Regional Autonomy in North Moluccas. Hasanuddin Law Review, vol. 4, no.2, 242-255.

Djakara, S. (2003). Niyaku Toudano Maulud Tumenggung Sis Dan Orang Jaton. Manado: BKSNT dan Laboratorium Antropologi Fisip Unsrat.

Konoras, A. (2017). Eksistensi Hukum Islam dan Hukum Adat dalam Sistem Hukum Nasional. Jurnal Ilmiah Al-Syir'ah, vol. 14, no. 2, 1-13.

Hasil Wawancara dengan Aqilla Fadia Sumohardjo (2nd Winner Indonesian Model Search 2018) Manado. 24 Desember 2018.

Hasil Wawancara dengan Eske Tumiwa (Tetuah Suku Minahasa). Manado, 24 Desember 2018.

Hasil Wawancara dengan Irwan Musa. Manado, 20 Desember 2017.

Hasil Wawancara dengan Sony Samual. Manado, 31 Mei 2017.

Mamonto, A. R., \& Muhammad, N. E. (2019). The Pogogutat Tradition of the Mongondow Tribe in North Sulawesi on Maslahah Mursalah Perspective. Al-Mizan, Vol. 15, no. 1, 33-54.

Mantu, R. (2015). Memaknai Torang Samua Basudara: Manajemen Dakwah Berbasis Kearifan Lokal Di Kota Manado. Jurnal Ilmiah Potret Pemikiran, vol. 19, no. 2, 42-65.

Salim, D. P. (2017). Kerukunan Umat Beragama vs Kebebasan Beragama di Indonesia. Jurnal Potret Pemikiran, Vol. 21, no. 2, 1534.

Setiady, T. (2009). Intisari Hukum Adat Indonesia. Bandung: Alfabeta. 


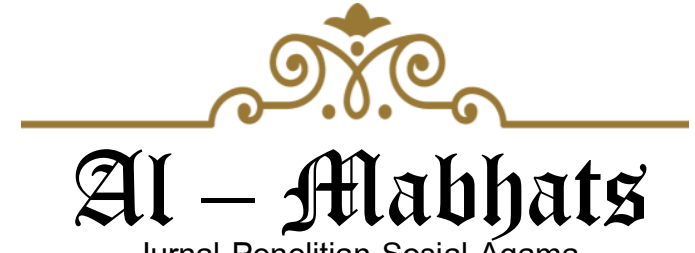

Jurnal Penelitian Sosial Agama

Vol. 4 No. 22019

Soyomukti, N. (2016). Pengantar Sosiologi Dasar Analisi, Teori, E Pendekatan Menuju Analisi Masalah-Masalah Sosial, Perubahan Sosial, \& Kajian-Kajian Strategis. Jakarta: Ar-Ruz Media.

Sulutprov. (2017). Mengenal Sejarah Sulawesi Utara. Diakses pada 17 Agustus 2017, dari http://www.sulutprov.go.id/mengenal-sulut/sejarah/ Sumanto, D. (2018). Hukum Adat di Indonesia Perspektif Sosiologi dan Antropologi Hukum Islam. JURIS (Jurnal Ilmiah Syariah), vol. 17, no. 2, 181-191.

Tanya, B. L., Simanjuntak, Y. N., \& Hage, M. Y. (2007). Teori Hukum. Surabaya: CV Kita.

Tumenggung Sis, M. (2003). Tradisi Ba'do Ketupat Masyarakat Jaton Di Sulawesi Utara. Manado: BKSNT dan Laboratorium Antropologi Fisip Unsrat.

Wikipedia. (2017). Sulawesi Utara. Diakses pada 17 Agustus 207 dari https://id.wikipedia.org/wiki/Sulawesi_Utara Yewangoe. (2011). Agama dan Kerukunan. Jakarta: BPK. 